\title{
The Effects of Temperature and Salinity Stressors on the Survival, Condition and Valve Closure of the Manila Clam, Venerupis philippinarum in a Holding Facility
}

\author{
Hyeonmi Bae ${ }^{1,2}$, Jibin Im ${ }^{1,2}$, Soobin Joo ${ }^{1,2}$, Boongho Cho ${ }^{1,2}$ and Taewon Kim ${ }^{1,2, *(D)}$ \\ 1 Department of Ocean Sciences, Inha University, 100 Inha-ro, Michuhol-gu, Incheon 22212, Korea; \\ qogusala@gmail.com (H.B.); dlawlqls2307@gmail.com (J.I.); soobinism94@gmail.com (S.J.); \\ boonghocho@gmail.com (B.C.) \\ 2 Program in Biomedical Science and Engineering, Inha University, 100 Inha-ro, Michuhol-gu, \\ Incheon 22212, Korea \\ * Correspondence: ktwon@inha.ac.kr; Tel.: +82-10-8726-3070
}

Citation: Bae, H.; Im, J.; Joo, S.; Cho, B.; Kim, T. The Effects of Temperature and Salinity Stressors on the Survival, Condition and Valve Closure of the Manila Clam, Venerupis philippinarum in a Holding Facility. J. Mar. Sci. Eng. 2021, 9, 754. https:// doi.org/10.3390/jmse9070754

Academic Editor: Laura G. Peteiro

Received: 10 June 2021

Accepted: 5 July 2021

Published: 8 July 2021

Publisher's Note: MDPI stays neutral with regard to jurisdictional claims in published maps and institutional affiliations.

Copyright: (c) 2021 by the authors. Licensee MDPI, Basel, Switzerland. This article is an open access article distributed under the terms and conditions of the Creative Commons Attribution (CC BY) license (https:// creativecommons.org/licenses/by/ $4.0 /)$.

\begin{abstract}
We investigated the response of the Manila clam Venerupis philippinarum to possible temperature and salinity changes in a holding facility. First, clams were exposed to four temperatures for 15 days. Valve closure and survival of clams exposed to seawater at $18^{\circ} \mathrm{C}$ were higher than that of those exposed to seawater at $24^{\circ} \mathrm{C}$. Second, clams were exposed to six salinities for 15 days. Survival of clams exposed to two salinity fluctuation conditions (24-30 and 27-24 psu) was lower than that of clams exposed to constant 30 psu conditions. Valve closures of clams exposed to constant low salinity conditions ( $24 \mathrm{psu}$ ) and two salinity fluctuation conditions (24-30 and 27-24 psu) were higher than those exposed to constant 30 psu conditions. Lastly, clams were exposed to two different temperatures and three different salinity conditions for 8 days. Valve closure and survival decreased significantly under the combination of $24^{\circ} \mathrm{C}$ and $18 \mathrm{psu}$. These results suggest that an increase in temperature or a wider range of salinity fluctuations are detrimental to the survival of the Manila clam. The synergistic effect of temperature and salinity stressors may decrease the survival period of clams compared to the effect of a single stressor.
\end{abstract}

Keywords: warming; freshening; salinity fluctuation; multiple stressors; stock holding

\section{Introduction}

Increased anthropogenic greenhouse gas emissions have contributed to climate-related changes, such as global warming and extreme weather events, according to the Intergovernmental Panel on Climate Change report [1]. The global mean surface temperature is predicted to increase by $1.0-3.7^{\circ} \mathrm{C}$ by 2100 [2]. In addition, the number of melting glaciers, the frequency and intensity of heavy rainfall events, and the input of freshwater from rivers may increase, due to global warming [3,4]. These events can affect the marine ecosystem, especially through direct effects on marine organisms in the coastal zone [5,6].

Estuaries are among the most ecologically and economically important environments and are sensitive to the effects of climate change [7,8]. Temperature and salinity are important environmental factors affecting the survival of marine benthic organisms, and increasing temperatures and decreasing salinity can act as dominant physical stressors [9]. The reported effects of an increase in temperature include changes in growth [10,11], behavior [12,13], metabolism [14,15], and mortality [12,16]. Salinity effects include abnormal endogenous rhythms [17], changes in behavior [18-20], decreased condition index [21,22], and increased mortality [23]. Short-term temperature and salinity stressors, such as heatwaves and heavy rainfall, can threaten growth, recruitment, and survival at the population level [24,25]. To date, there have been many studies on the single-stressor effects, but studies on the effect of combined stressors are limited. The combination of temperature and salinity effects results in reduced energy [26], and increased mortality [27]. The 
combination of multiple stressors may induce both additive, synergistic, or antagonistic responses $[16,28,29]$. Therefore, it is important to understand the effects of both single and combined stressors to estimate the ecological impact of climate change on marine benthic animals and economic damage in aquaculture [30,31].

Bivalves are valuable biological resources in estuaries and are generally harvested when they grow to market size [9]. Once harvested, fresh bivalves are transported to the local market. However, extreme weather conditions and unforeseen problems may delay the timely transport of bivalves to the market, and bivalves can spend extended time in holding facilities [32,33]. In these situations, bivalves can face fluctuating physical stressors during the holding period [34,35]. Because the water used at the holding facilities is pumped up from the surrounding bay, the bivalves in the facility may be exposed to similar temperature and salinity conditions as those in the field [35]. Several experimental studies have investigated the influence of exposure to fluctuating physical stressors on the survival of bivalves during the holding period, but most of them focused on mussels, which are epifaunal species with a high frequency of extended exposure to the air [32-36]. Conversely, studies on clams, which are infaunal species with a relatively low frequency of exposure to the air, are very rare.

In consideration of this, we investigated the response of the Manila clam, Venerupis philippinarum, to possible temperature and salinity changes in a holding facility. V. philippinarum is distributed in the northwest Pacific coasts, such as Korea, Japan, China, and the Philippines, and has been introduced to Europe and North America [37,38]. V. philippinarum is an infaunal suspension-feeding bivalve with high ecological and commercial importance $[37,39,40]$.

We hypothesized that the impact of climate-related events would negatively affect the survival and behavior of $V$. philippinarum in the holding facility. Three experiments were conducted to test this hypothesis. First, to determine the effect of increasing temperature, the clams were exposed to four treatments of varying temperatures under constant salinity. Second, to determine the effect of decreasing salinity and fluctuations in salinity, clams were exposed to six different salinity treatments under constant temperature. Lastly, to determine the effect of the combined temperature and salinity changes, clams were exposed to two different temperatures and three different salinity conditions.

\section{Materials and Methods}

\subsection{Collection and Acclimation}

For Experiment 1, V. philippinarum were collected from Gunpyeong-ri in the Yellow Sea, Korea $\left(37^{\circ} 07^{\prime} 05.1^{\prime \prime} \mathrm{N}, 126^{\circ} 36^{\prime} 47.5^{\prime \prime}\right.$ E). For Experiment 2 and Experiment 3, $V$. philippinarum that were originally cultured from Muui-Do in the Yellow Sea, Korea $\left(37^{\circ} 23^{\prime} 31.7^{\prime \prime} \mathrm{N}, 126^{\circ} 24^{\prime} 56.0^{\prime \prime} \mathrm{E}\right)$ were purchased from a local market located in Incheon, Korea $\left(37^{\circ} 27^{\prime} 13.6^{\prime \prime} \mathrm{N}, 126^{\circ} 36^{\prime} 22.4^{\prime \prime} \mathrm{E}\right)$. The collected clams were transported to the laboratory in an icebox. In the laboratory, the clams were placed in six acclimation tanks $(60 \mathrm{~L}, 38 \mathrm{~cm} \times 55 \mathrm{~cm} \times 30 \mathrm{~cm}, \mathrm{~W} \times \mathrm{L} \times \mathrm{H})$ without added food for 7-8 days to maintain the same gut condition of individuals before the experiment. The water was recirculated using a filter media and a pump. After acclimation, they were individually marked using a paint marker (Kangnam Kpi Co., Seoul, Korea), and their shell lengths were measured with digital calipers (CD-15PSX, Mitutoyo Corp., Kanagawa, Japan) to the nearest 0.01 $\mathrm{mm}$. Water temperature and salinity were measured using a YSI pro2030 (Yellow Spring Instruments Inc., OH, USA) twice every day. The water temperature at each treatment was maintained during the experiment using a water bath and heaters (BS-3000, Dong-woo Electric, Daegu, Korea), while salinity at each treatment was attained by adding artificial sea salt (Red Sea, HO, USA).

\subsection{Experimental Setup}

In each experiment, large experimental chambers $(126 \mathrm{~L}, 75 \mathrm{~cm} \times 80 \mathrm{~cm} \times 20 \mathrm{~cm}$, $\mathrm{W} \times \mathrm{L} \times \mathrm{H}$ ) were used and continuously aerated using an air pump (YP-15A, Youngnam, Busan, Korea). In each chamber, water was pumped through a filter (EHEIM Professionel 
4 + 250, EHIM GmbH and Co. KG, Deizisau, Germany) and one cooler (DAEIL DBC-150, Daeil, Busan, Korea) (Figure 1a) and then entered via a hose to each jar containing clams in a submerged net pot (Figure 1b). The water of the jars was overflowed into each chamber and circulated. The photoperiod followed a 12/12-h light/dark cycle.

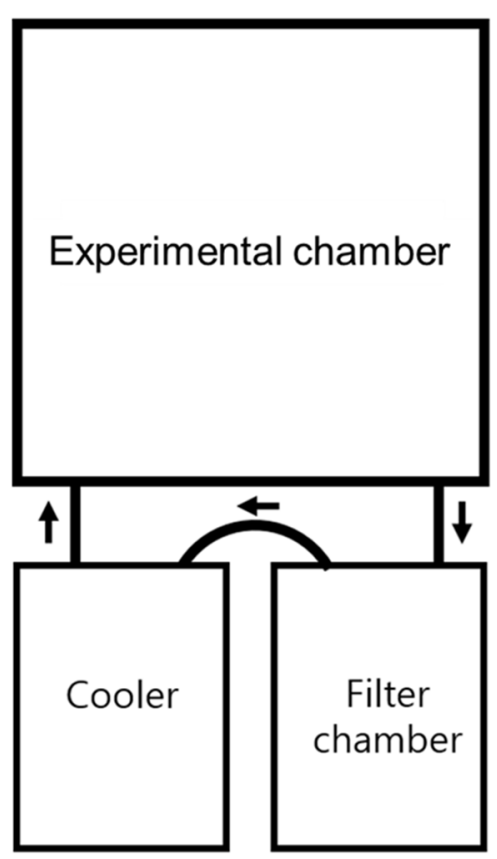

(a)

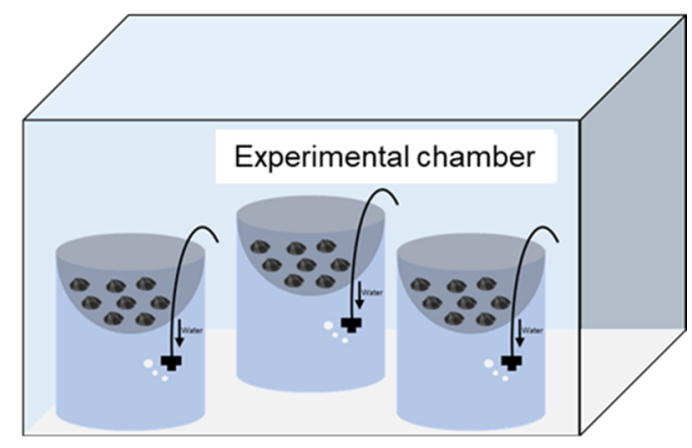

(b)

Figure 1. (a) Diagram of the experimental setup and (b) diagram of each experimental chamber.

\subsubsection{Temperature (Experiment 1$)$}

To investigate the effect of temperature on the survival and behavioral response of V. philippinarum, the first experiment was conducted from 21 September to 5 October 2018. A total of 360 clams [shell length (SL) $33.51 \pm 0.095 \mathrm{~mm}$ : mean \pm standard error (SE)] were randomly selected from the acclimation tank of each treatment. Acclimation tanks were maintained at $15{ }^{\circ} \mathrm{C}$ on the first day and then increased by $1.5^{\circ} \mathrm{C}$ per day to the experimental conditions for each treatment for seven days. $\left(T=15^{\circ} \mathrm{C}, 18^{\circ} \mathrm{C}, 21^{\circ} \mathrm{C}\right.$, and $24^{\circ} \mathrm{C}$; Sal $=30 \mathrm{psu}$ ). Nine clams were allocated to each replicate. Ten replicates per treatment were placed inside each experimental chamber. The clams were maintained under four temperature treatments $\left(15^{\circ} \mathrm{C}, 18^{\circ} \mathrm{C}, 21^{\circ} \mathrm{C}\right.$, and $\left.24^{\circ} \mathrm{C}\right)$ for 15 days according to the regular seawater temperatures recorded between May and August at the rearing site (Sea Grant Gyeonggi, Korea). An ambient salinity of 30 psu was maintained throughout all four experimental conditions.

\subsubsection{Salinity (Experiment 2)}

To investigate the effect of different salinity conditions (low salinity and salinity fluctuations) on V. philippinarum, the second experiment was conducted from 12 June to 26 June 2020. A total of 384 clams (SL $33.52 \pm 0.091 \mathrm{~mm}$ : mean \pm SE) were randomly selected from the acclimation tank, which maintained steady conditions for seven days. $\left(T=21^{\circ} \mathrm{C} ; \mathrm{Sal}=30 \mathrm{psu}\right)$. Eight clams were allocated to each replicate. Eight replicates per treatment were placed inside the experimental chamber (Figure 2a). The clams were maintained under six experimental conditions for 15 days. We exposed clams to the following experimental treatments at a constant temperatures $\left(21^{\circ} \mathrm{C}\right)$ : (1) Constant salinity $(24,27$, and $30 \mathrm{psu})$ and (2) fluctuating salinity (24-30, 27-24, and 30-27 psu). These salinity ranges correspond to those experienced by Manila clams in the holding tank during the summer season (Sea Grant Gyeonggi). Fluctuating salinity was obtained using the 
following steps (Figure 2): First, clams were immersed in the initial salinity chambers for $12 \mathrm{~h}$. Second, the net pot was moved to the chamber with the next scheduled salinity treatment. The net pot was then moved to the initial salinity chamber. This procedure was repeated daily. Clams were fed $10 \mathrm{~mL}$ of Shellfish Diet $1800^{\circledR}(20,000$ cells $/ \mathrm{mL}$; Reed Mariculture Inc., Campbell, CA, USA) twice a day.

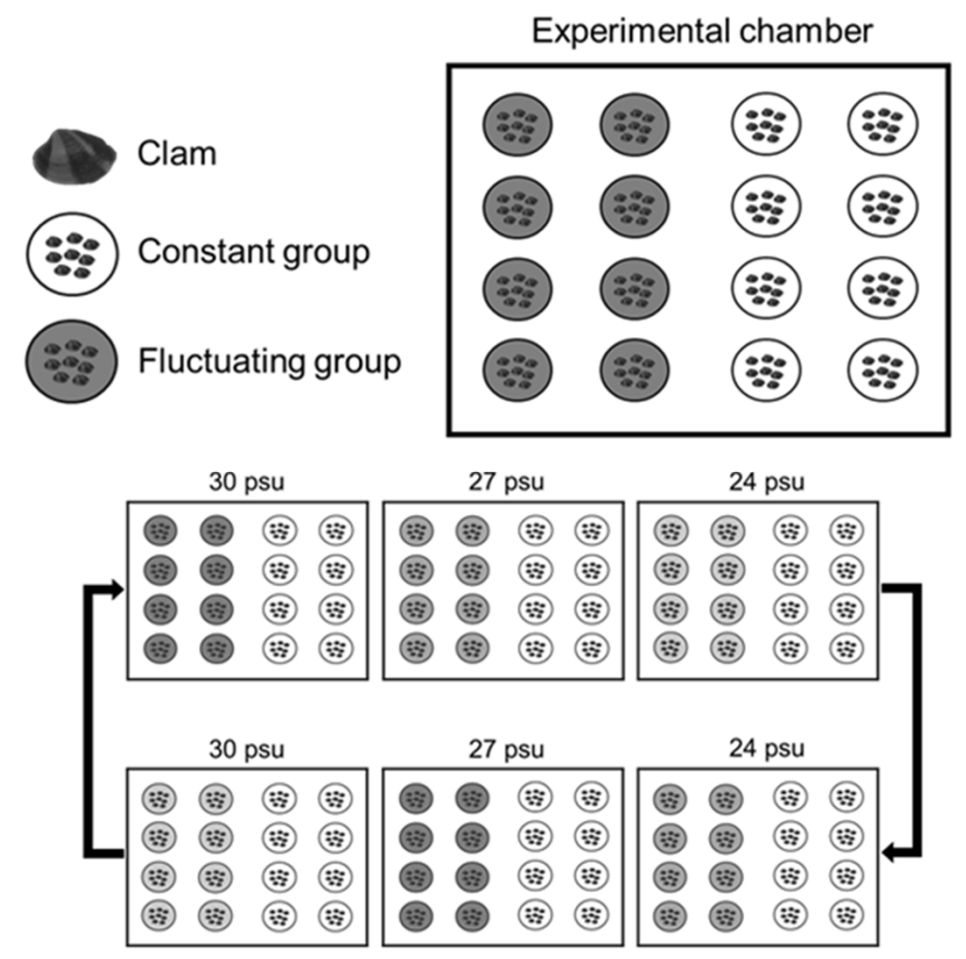

(a)

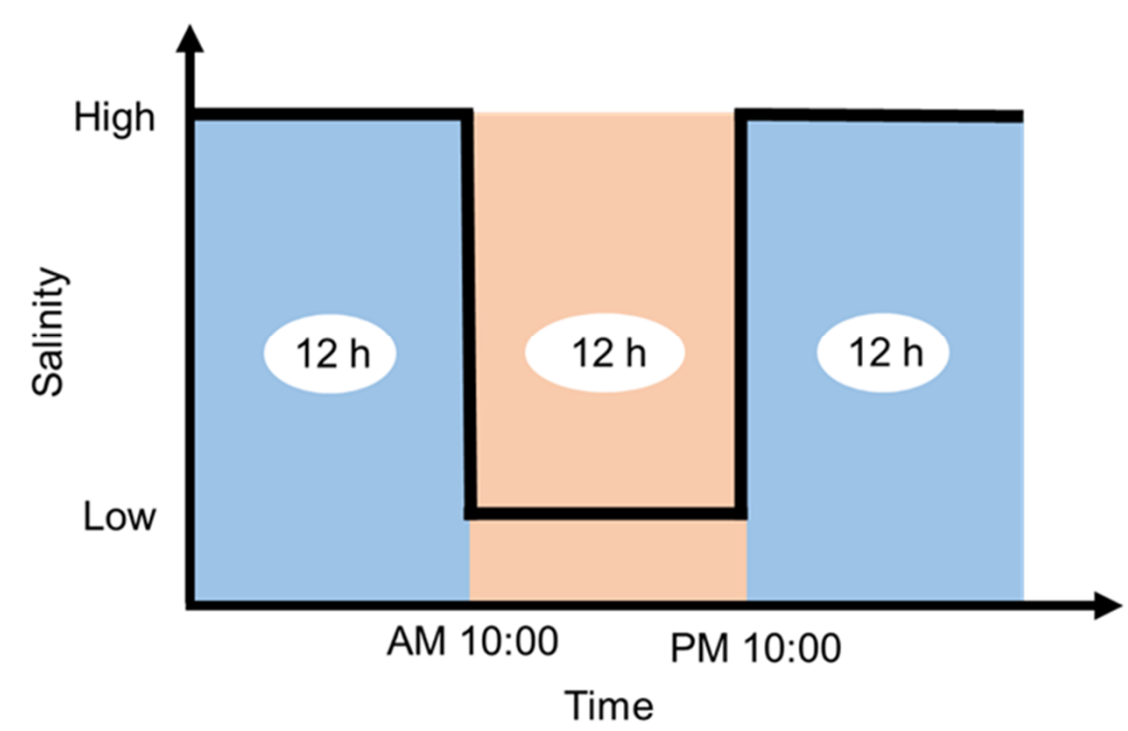

(b)

Figure 2. (a) Schematic diagram of Experiment 2 setup and (b) an example of the salinity fluctuation procedure of Experiment 2. 


\subsubsection{Temperature and Salinity (Experiment 3)}

The results of Experiment 1 and Experiment 2 showed no significant difference in mortality between $21^{\circ} \mathrm{C}$ and $24{ }^{\circ} \mathrm{C}$, or between 30,27 , and 24 psu (see the Results). Thus, to investigate the combined effect of temperature and salinity on V. philippinarum, we conducted an additional experiment based on these results from 10 October to 17 October 2020. A total of 576 clams (SL $34.33 \pm 0.15 \mathrm{~mm}$; mean \pm SE) were randomly selected from the acclimation tank where they were maintained under steady conditions for eight days $\left(T=21^{\circ} \mathrm{C}\right.$; Sal $\left.=24 \mathrm{psu}\right)$. Eight clams were allocated to each replicate. Twelve replicates per treatment were placed inside each experimental chamber. The clams were maintained under six experimental conditions for eight days. We exposed clams to the following experimental treatments with two different levels of temperature and three different levels of salinity: (1) Low temperature and low salinity (LTLS, $21^{\circ} \mathrm{C}$, and $18 \mathrm{psu}$ ); (2) low temperature and middle salinity (LTMS, $21^{\circ} \mathrm{C}$, and $21 \mathrm{psu}$ ); (3) low temperature and high salinity (LTHS, $21^{\circ} \mathrm{C}$, and $24 \mathrm{psu}$ ); (4) high temperature and low salinity (HTLS, $24^{\circ} \mathrm{C}$, and $18 \mathrm{psu}$ ); (5) high temperature and middle salinity (HTMS, $24^{\circ} \mathrm{C}$, and $21 \mathrm{psu}$ ); and (6) high temperature and high salinity (HTHS, $24^{\circ} \mathrm{C}$, and $24 \mathrm{psu}$ ). The temperature and salinity treatment values were selected according to the range of natural variations of those parameters observed at the holding facility thereabouts at the rearing site (Sea Grant Gyeonggi). The clams were fed $10 \mathrm{~mL}$ of Shellfish Diet $1800^{\circledR}(20,000$ cells $/ \mathrm{mL}$; Reed Mariculture Inc.) twice a day.

\subsection{Measurements}

Mortality, condition index, and valve closure were measured in Experiments 1 and 2. Mortality and valve closure were measured in Experiment 3.

\subsubsection{Mortality}

The number of dead individuals was checked in each jar at 10:00 and 22:00 daily during the experimental period. A clam was determined as "dead" when it maintained the gaping valve or showed decreased closure power of the shell despite mechanical stimulus $[9,41]$. Mortality was calculated as follows:

$$
\text { Mortality }(\%)=\frac{\text { No. of dead individuals }}{\text { Original no. of individuals }} \times 100
$$

\subsubsection{Condition Index (CI)}

The condition index $(\mathrm{CI})$ is an ecological and physiological indicator that is widely used to assess bivalve fitness and the effects of environmental stresses [21,36]. After each experiment, separated weights for tissues and shells were obtained after dissecting and drying in an oven (VS-1202D3-S, Vision, Bucheon, Korea) at $65{ }^{\circ} \mathrm{C}$ for $48 \mathrm{~h}$ and then weighted using an electronic microbalance (PX224KR/E, Ohaus, NJ, USA). CI was calculated according to the formula provided by Walne (1976) [42]:

$$
C I=\frac{\text { Dry tissue weight }(g)}{\text { Dry shell weight }(g)} \times 100
$$

\subsubsection{Valve Closure}

During the experimental period, the number of clams closing their valves in each jar was checked daily at 09:00 and 21:00. The percentage of individuals with valve closure was calculated as follows:

$$
\text { Valve closure }(\%)=\frac{\text { No. of valve closure individuals }}{\text { No. of individuals in each replicate }} \times 100
$$




\subsection{Statistical Analysis}

Arcsine square root transformations were performed on all proportional data (mortality and valve closure rate of clams). In Experiments 1 and 2, we conducted Kruskal-Wallis $H$ test to determine whether the mortality and condition index was influenced by temperature or salinity. If there was a significant difference in the Kruskal-Wallis $H$ test, Dunn's test was performed as a post-hoc test for multiple comparison analysis. When there was no significant difference in the Kruskal-Wallis $H$ test, however, Mann-Whitney $U$ tests were used to detect the significant difference between the two treatment groups independently (e.g., $15^{\circ} \mathrm{C}$ vs. $18^{\circ} \mathrm{C}, 15^{\circ} \mathrm{C}$ vs. $21^{\circ} \mathrm{C}, 15^{\circ} \mathrm{C}$ vs. $24^{\circ} \mathrm{C}, 18^{\circ} \mathrm{C}$ vs. $21^{\circ} \mathrm{C}, 18^{\circ} \mathrm{C}$ vs. $24^{\circ} \mathrm{C}$, and $21^{\circ} \mathrm{C}$ vs. $24^{\circ} \mathrm{C}$ ). In Experiment 3, a two-way ANOVA was used to determine whether mortality was influenced by combining the two temperatures and three salinities. In all experiments, a repeated-measures ANOVA was applied to determine the effects of each factor on valve closure because not only the independent variable (temperature, salinity, or combining temperature and salinity), but also time can affect valve closure. If there was a significant difference, Tukey's post-hoc test was applied. When sphericity (equality of variance) was violated (Mauchly's test, $p<0.05$ ), Huynh-Feldt corrections were applied. Statistical analyses were conducted using SPSS ver. 19.0 (IB8M Corp., Armonk, NY, USA).

\section{Results}

\subsection{Temperature (Experiment 1)}

There was no significant difference in mortality between treatments (Kruskal-Wallis $H$ test; $\mathrm{x}^{2}=6.034, \mathrm{df}=3, p=0.110$; Figure $3 \mathrm{a}$ ). However, mortality was significantly different between the $18{ }^{\circ} \mathrm{C}$ and $24^{\circ} \mathrm{C}$ conditions (two-tailed Mann-Whitney $U$ test; $18^{\circ} \mathrm{C}$ vs. $24^{\circ} \mathrm{C}: U=17.5, \mathrm{n}_{1}=9, \mathrm{n}_{2}=9, p=0.032$ ). The mortality rate at $24^{\circ} \mathrm{C}$ was the highest. There was no significant difference in $\mathrm{CI}$ between different temperatures (Kruskal-Wallis $H$ test; $\mathrm{x}^{2}=5.034, \mathrm{df}=3, p=0.169$; Figure $3 \mathrm{c}$ ). There was a significant difference in valve closure between treatments (repeated measures ANOVA; $\mathrm{F}_{3,32}=3.446, p=0.028$; Figure $3 \mathrm{~b}$ ). Individuals were significantly more inactive at $18{ }^{\circ} \mathrm{C}$ than at $24{ }^{\circ} \mathrm{C}$ (Tukey's post hoc test; $p=0.018$ ).

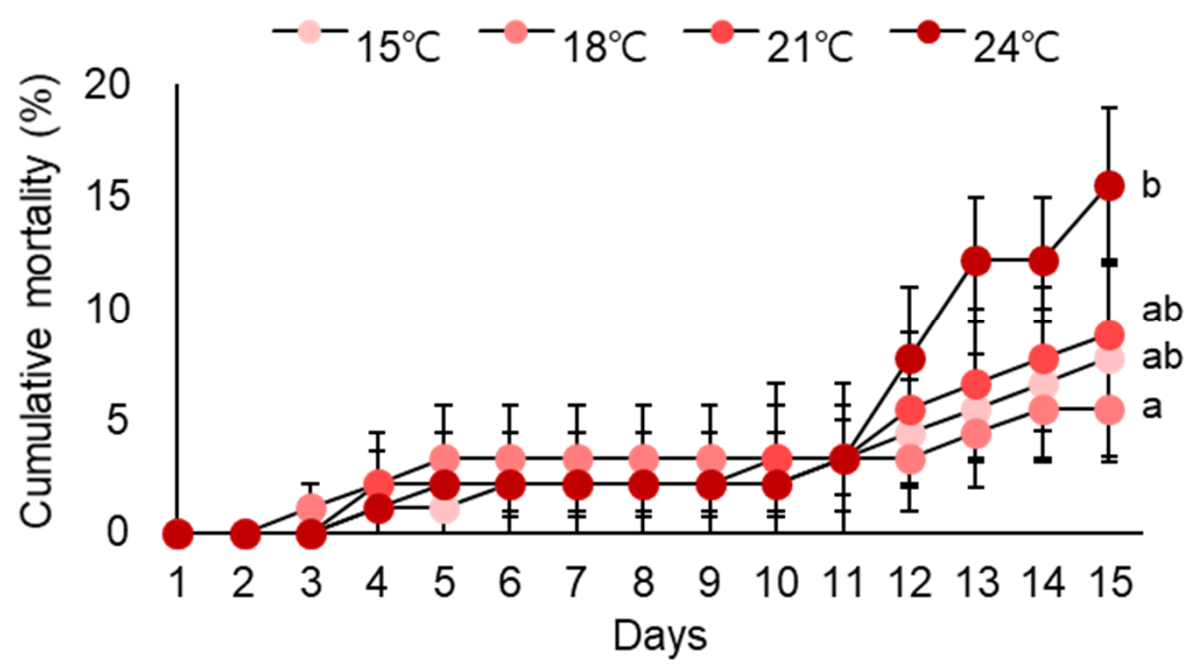

(a)

Figure 3. Cont. 


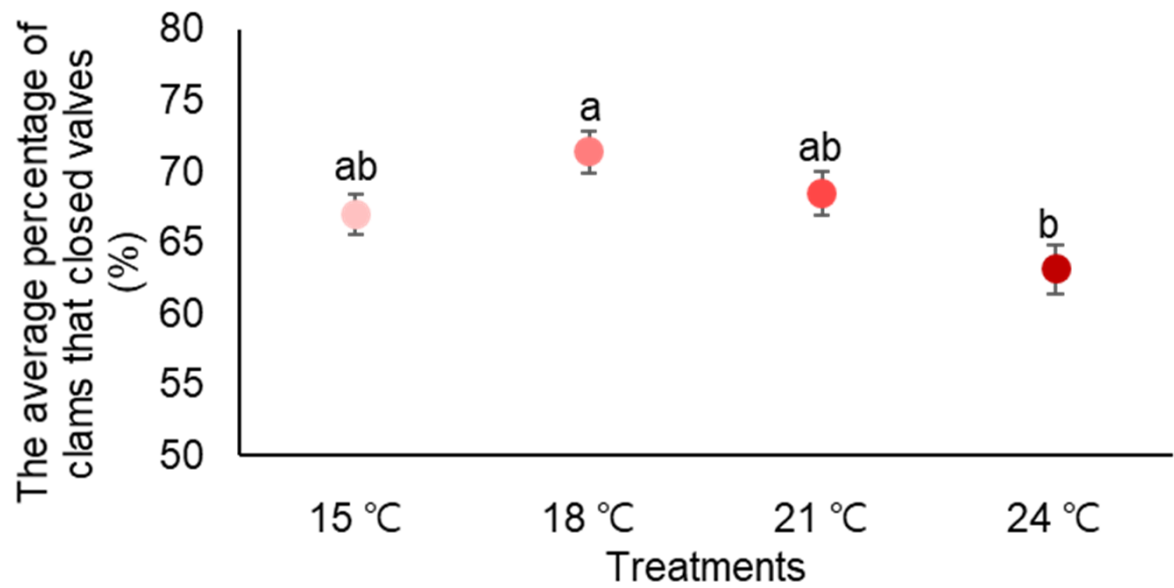

(b)

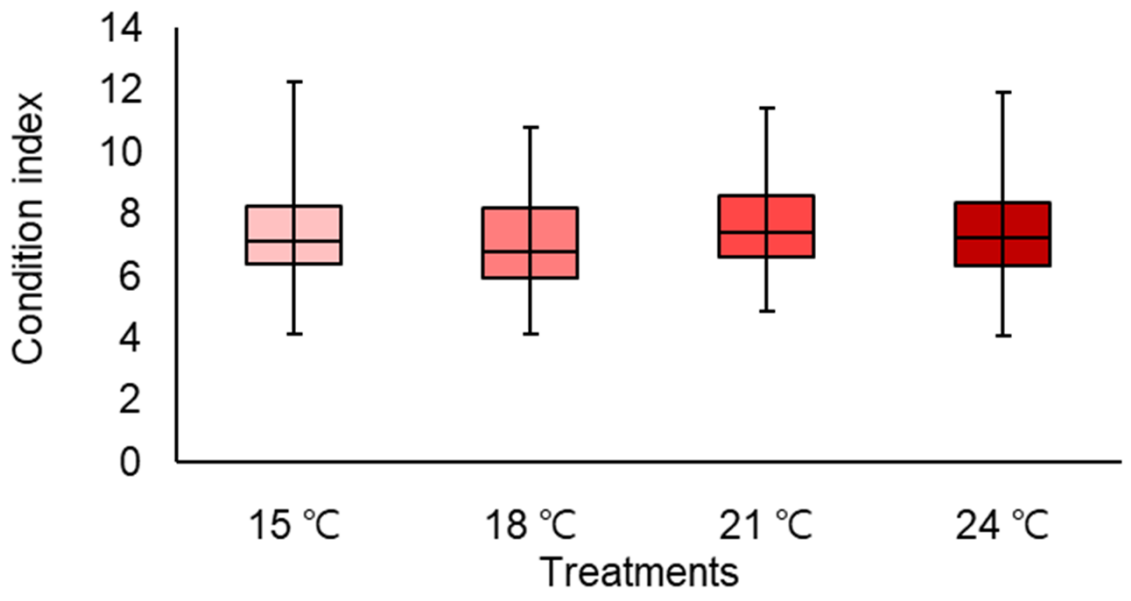

(c)

Figure 3. (a) Cumulative mortality rate (mean $\pm \mathrm{SE}$ ), (b) the average proportion of valve closure (mean $\pm \mathrm{SE}$ ), and (c) condition index (mean $\pm \mathrm{SE}$ ) of Venerupis philippinarum during exposure to different temperatures $\left(15^{\circ} \mathrm{C}, 18^{\circ} \mathrm{C}, 21^{\circ} \mathrm{C}\right.$, and $\left.24^{\circ} \mathrm{C}\right)$ for 15 days. Different letters indicate significant differences between treatments $(p<0.05)$.

\subsection{Salinity (Experiment 2)}

There was a significant difference in mortality between treatments (Kruskal-Wallis $H$ test; $\mathrm{x}^{2}=12.513, \mathrm{df}=5, p=0.028$; Figure 4a). Although the mortality under constant conditions did not significantly differ between the various treatments ( 24 vs. 27 vs. 30 psu), mortality under fluctuating conditions did differ significantly between 24-30 psu and 30-27 psu (Dunn's test; $p=0.016$ ). In addition, the mortality of individuals exposed to two fluctuating salinity conditions (24-30 psu, 27-24 psu) was higher than those exposed to a constant 30 psu (Dunn's test; $24-30$ psu vs. 30 psu: $p=0.005 ; 27-24$ psu vs. 30 psu: $p=0.033)$. There were no significant differences in CI between the different treatments (Kruskal-Wallis $H$ test; $\mathrm{x}^{2}=2.272, \mathrm{df}=5$, $p=0.810$; Figure $4 \mathrm{c}$ ). There was a significant difference in valve closure between treatments (repeated measures ANOVA; $\mathrm{F}_{5,42}=4.713, p=0.002$; Figure $4 \mathrm{~b}$ ). The valve closure under constant conditions was significantly different between 24 and 30 psu (Tukey's post hoc test; 30 psu vs. 24 psu: $p=0.018$ ). Valve closure under fluctuating conditions showed no significant differences between different treatments (24-30 vs. 27-24 vs. 30-27 psu). Clams were significantly more active when exposed to constant salinity of $30 \mathrm{psu}$ than to constant salinity of 24 psu or fluctuating salinity conditions (24-30 and 27-24 psu) (Tukey's post hoc test; 30 psu vs. $24-30$ psu: $p=0.022 ; 30$ psu vs. $27-24$ psu: $p=0.021$ ). 


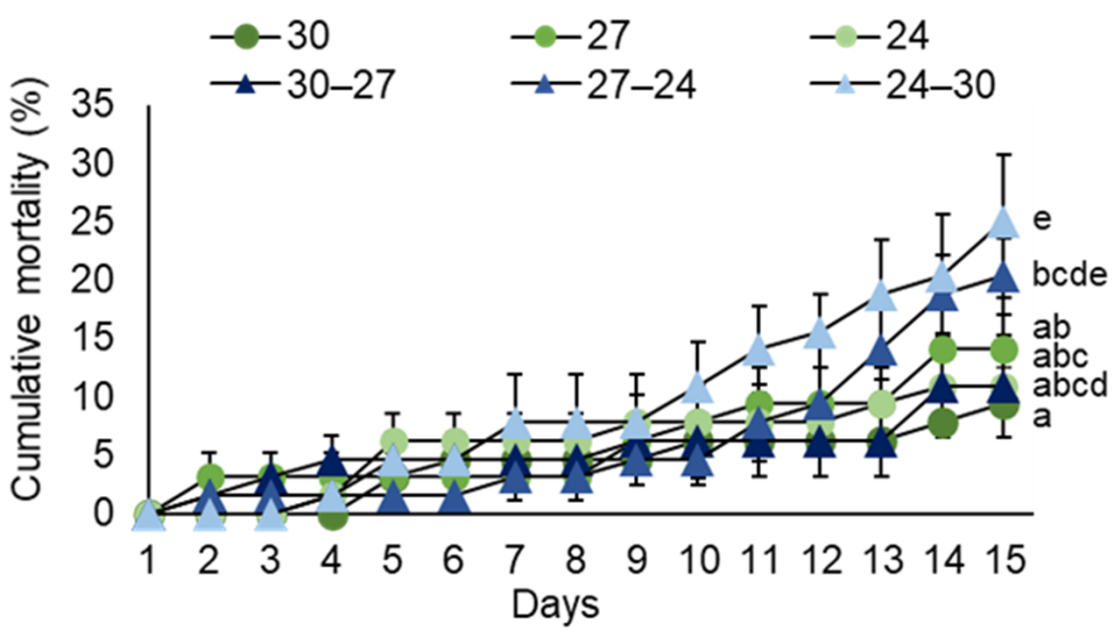

(a)

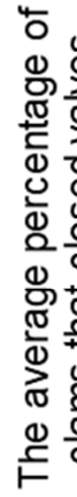

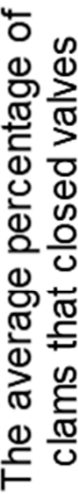

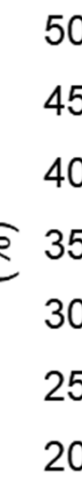

50
45
40
35
30
25
20
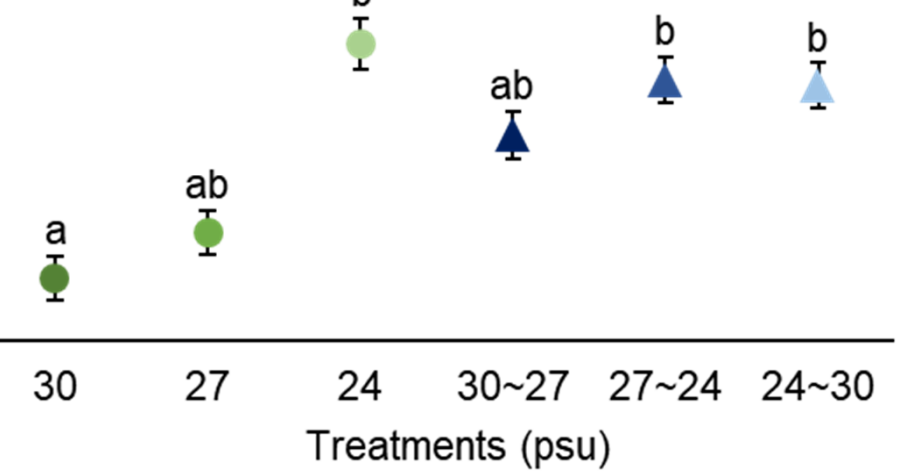

(b)

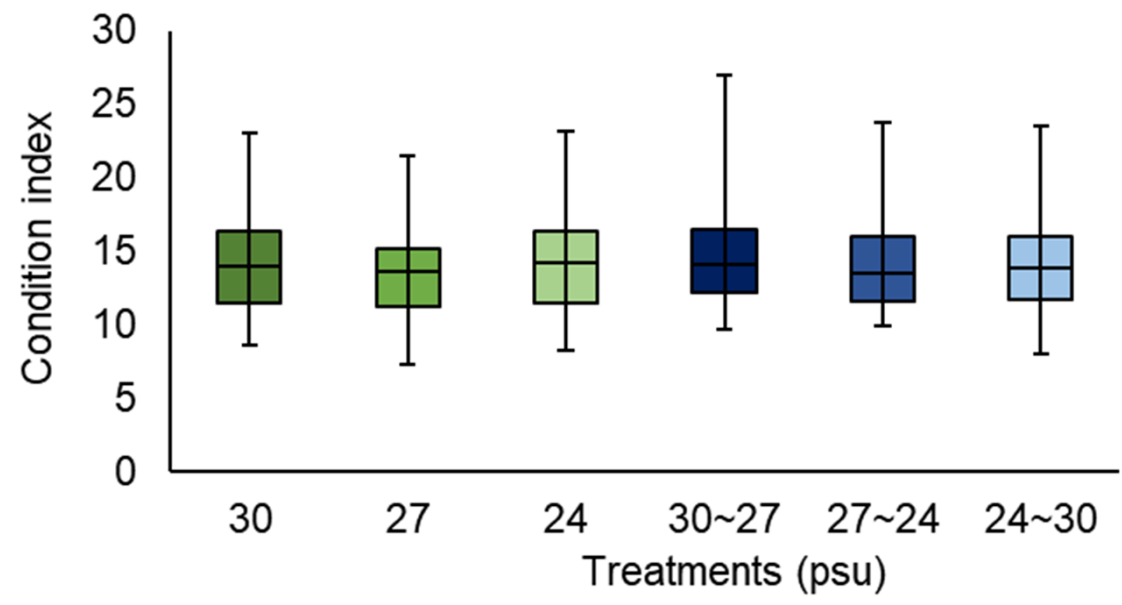

(c)

Figure 4. (a) Cumulative mortality rate (mean $\pm \mathrm{SE}$ ), (b) the average proportion of valve closure (mean $\pm \mathrm{SE}$ ), and (c) condition index (mean $\pm \mathrm{SE}$ ) of Venerupis philippinarum during exposure to different salinities (constant condition: 30, 27, and 24 psu, fluctuating condition: 30-27, 27-24, and 24-30 psu) for 15 days. Different letters indicate significant differences between treatments $(p<0.05)$. 


\subsection{Temperature and Salinity (Experiment 3)}

Temperature, salinity, and the interaction between the two factors significantly influenced mortality (two-way ANOVA, temperature: $\mathrm{F}_{1,66}=36.690, p<0.001$; salinity: $\mathrm{F}_{2,66}=3.533, p=0.035$; temperature $\times$ salinity: $\mathrm{F}_{2,66}=4.099, p=0.021$; Figure 5a). After eight days of exposure, mortality significantly increased at a water temperature of $24{ }^{\circ} \mathrm{C}$ and at a salinity of $18 \mathrm{psu}$. The highest mortality was observed under the combination of high temperature $\left(24^{\circ} \mathrm{C}\right)$ and low salinity (18 psu). Temperature, salinity, and the interaction between the two factors also significantly influenced valve closure (Figure $5 b$ and Table 1). The valve closure was significantly lower at a water temperature of $24^{\circ} \mathrm{C}$ and at a salinity of $18 \mathrm{psu}$ than that at low temperatures $\left(21^{\circ} \mathrm{C}\right)$ and /or high salinity ( $\left.24 \mathrm{psu}\right)$. The lowest valve closure was observed under the combination of high temperature $\left(24^{\circ} \mathrm{C}\right)$ and low salinity (18 psu).

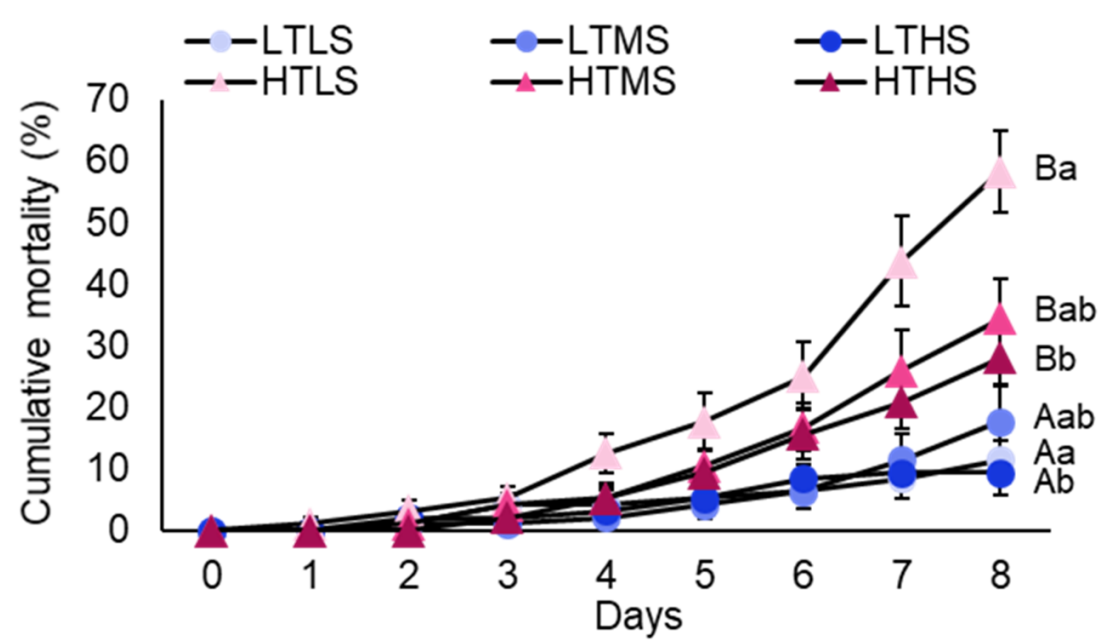

(a)
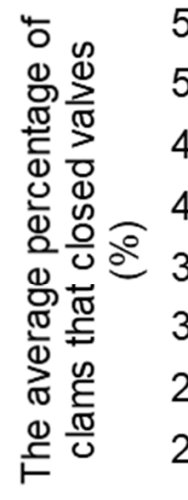

55
50
45
40
35
30
25
20
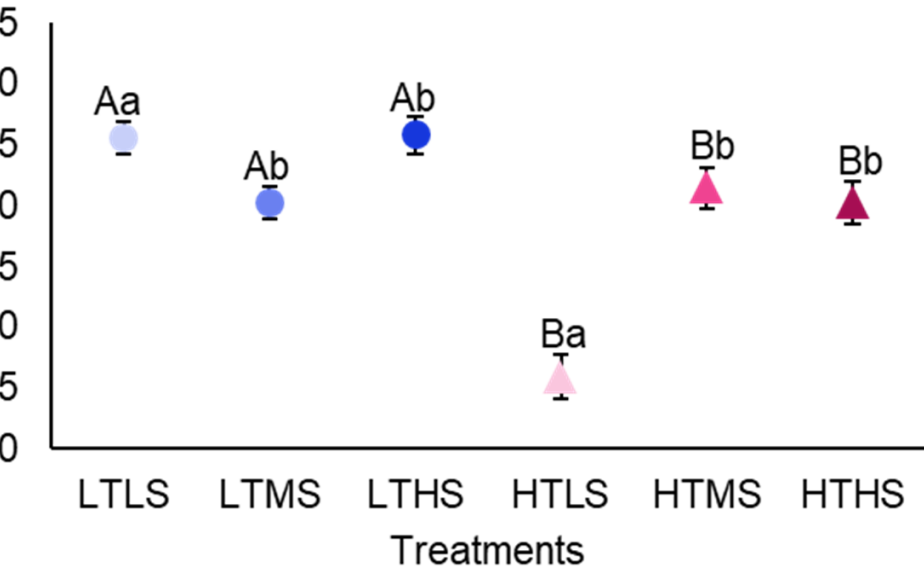

(b)

Figure 5. (a) Cumulative mortality rate (mean $\pm \mathrm{SE}$ ) and (b) the average proportion of valve closure (mean $\pm \mathrm{SE}$ ) of Venerupis philippinarum during exposure to two different temperatures $\left(21^{\circ} \mathrm{C}\right.$ and $\left.24^{\circ} \mathrm{C}\right)$ and three different salinities $(18,21$, and $24 \mathrm{psu})$ for eight days. Different uppercase letters indicate significant differences between treatments for temperature, and different. Abbreviation: LTLS, low temperature and low salinity; LTMS, low temperature and middle salinity; LTHS, low temperature and high salinity; HTLS, high temperature and low salinity; HTMS, high temperature and middle salinity; HTMS, high temperature and high salinity. 
Table 1. Results of the two-way repeated-measures ANOVA for the effects of temperature and salinity on the valve closure of Venerupis philippinarum.

\begin{tabular}{cc}
\hline & Valve Closure \\
\hline Within-subject effect & \\
Day & $F_{380.987,5.773}=14.900$ \\
$p<0.001$ & $F_{380.987,5.773}=5.674$ \\
& $p<0.001$ \\
Day $\times$ Temperature & $F_{380.987,11.545}=4.542$ \\
& $p<0.001$ \\
Day $\times$ Salinity & $F_{380.987,11.545}=4.932$ \\
& $p<0.001$ \\
Day $\times$ Temperature $\times$ Salinity & \\
Between-subject effect & $F_{66,1}=28.418$ \\
Temperature & $p<0.001$ \\
Salinity & $F_{66,2}=8.584$ \\
& $p<0.001$ \\
Temperature $\times$ Salinity & $F_{66,2}=16.076$ \\
& $p<0.001$ \\
\hline
\end{tabular}

\section{Discussion}

\subsection{Temperature}

A reduction in valve closure and increased mortality at $24{ }^{\circ} \mathrm{C}$ compared to $18{ }^{\circ} \mathrm{C}$ were observed, although the $\mathrm{CI}$ of clams showed no significant differences between different temperatures $\left(15-24{ }^{\circ} \mathrm{C}\right)$ for 15 days. The results were similar to those of a previous study on the effects of temperature on juveniles $V$. philippinarum [16]. The increased mortality and behavior change at $24{ }^{\circ} \mathrm{C}$ may be a consequence of metabolic depression caused by high temperatures. Han et al. [10] reported that the thermal optimum in scope for growth (SFG) for adults $V$. philippinarum is $20^{\circ} \mathrm{C}$, and Nie et al. [43] found a reduction in oxygen consumption of adults V. philippinarum at temperatures $>25^{\circ} \mathrm{C}$. The mussel Mytilus galloprovincialis has a similar trend when exposed to high temperatures, as shown by the decrease in valve closure at a temperature above $26^{\circ} \mathrm{C}$, the increased mortality, and a reduction in SFG $[12,14]$.

Broadly, bivalves are poikilothermic animals that have a low ability to generate internal temperature through metabolic processes [44], and can maintain survival using low energy compared to that used by homeothermic animals of the same weight. Valve closure is a strategy used under stress [39], which saves metabolic energy and can be implemented under short-term stress $[12,20]$. However, $V$. philippinarum with aragonite shells, which have higher thermal conductivity, cannot avoid extreme temperatures through valve closure $[45,46]$. Therefore, temperatures over the optimal range may have a negative effect on $V$. philippinarum in the holding facility.

\subsection{Salinity}

Constant low-salinity conditions did not have a significant effect on mortality or CI; however, constant low salinity had a significant effect on the valve closure of the clams for 15 days. When exposed to salinities near or beyond their tolerance limits, the initial response of bivalves is valve closure. Prolonged valve closing periods may result in mortality, due to increased anaerobic metabolism and reduced filtration $[9,20]$. However, at salinities higher than $20 \mathrm{psu}$, the metabolic activities of $V$. philippinarum can recover to the original endogenous rhythm (measured oxygen consumption rate) within $12 \mathrm{~h} \mathrm{[17].} \mathrm{In}$ addition, several studies have reported that exposure to $24 \mathrm{psu}$ is within the optimal salinity range [23,47]. Nevertheless, Parada et al. [48] reported that long-term exposure to between 25 and 30 psu for approximately 30 days leads to severe mortality in V. philippinarum in the field. Our findings indicate that $V$. philippinarum can tolerate seawater at $24 \mathrm{psu}$ 
for 15 days; however, more prolonged exposure may lead to the accumulation of effects causing increased mortality.

Previous studies on the effect of salinity fluctuation on V. philippinarum showed that salinity above 24 psu did not influence mortality or valve movement [39,49]. For instance, Arisman et al. [49] reported that $V$. philippinarum exposed to $24 \mathrm{psu}$ at $18{ }^{\circ} \mathrm{C}$ for 30 days in a 3-h cycle per day did not show different results for mortality and immune response (measure of lysozyme activity) compared to individuals exposed to $34 \mathrm{psu}$. It was observed that $V$. philippinarum exposed to $25 \mathrm{psu}$ at $17^{\circ} \mathrm{C}$ in a 1-day cycle for 15 days did not differ in mortality or valve closure compared to those exposed to $30 \mathrm{psu}$. However, in this study, clams exposed to $24 \mathrm{psu}$ at $21^{\circ} \mathrm{C}$ for $12 \mathrm{~h}$ per day showed high mortality and valve closure. This suggests that the salinity fluctuation tolerance range for survival narrowed as the temperature increased, but further information about the metabolic response is needed to understand the combined effects of temperature and salinity fluctuation on the survival and behavior of $V$. philippinarum.

\subsection{Temperature and Salinity}

Temperature and salinity act not only as single stressors, but also as combined stressors. In this study, temperature, salinity, and the interaction between them significantly influenced mortality and valve closure. A reduction in valve closure and increased mortality at $24{ }^{\circ} \mathrm{C}$ compared to that at $21^{\circ} \mathrm{C}$ was observed. Based on the results of Experiments 1 and 3 , the $3{ }^{\circ} \mathrm{C}$ temperature increase had no significant effect when clams were exposed to $30 \mathrm{psu}$. However, when the salinity was less than $24 \mathrm{psu}$, the range of temperature at which $V$. philippinarum survived was narrowed.

Our findings support those of previous studies in that the temperature range at which the species survived became narrower as salinity decreased [27,50]. In addition, significantly increased mortality and decreased valve closure were observed after exposure to $18 \mathrm{psu}$ compared to that at $21 \mathrm{psu}$ and $24 \mathrm{psu}$ in this study. Unlike in Experiment 2, the reasons for the low valve closure in the high-mortality condition could be that the exposure to $18 \mathrm{psu}$ is close to their tolerance limit. Previous studies have reported that a temperature increase and a salinity decrease may lead to increases in cellular energy expenditure to maintain osmoregulation and induce mortality of hemocyte cells related to the bivalve immune system [51]. Salinity below 20 psu may cause abnormal metabolic activity and decreases the clearance rate $[17,52]$.

Synergistic interactions between multiple stressors are common in nature [29]. In this study, clam mortality was significantly higher under the $24^{\circ} \mathrm{C}$ temperature when combined with the $18 \mathrm{psu}$ condition. The interaction between temperature and salinity had a more significant effect on mortality in shorter periods compared to their individual effects in Experiments 1 and 2, respectively, and more than $50 \%$ of clams died after eight days of exposure. These results indicate that during the summer period, when extreme climate events occur, the combination of high temperature and low salinity may cause mortalities of V. philippinarum in the holding facility within 1-2 weeks.

\section{Conclusions}

Our study provides information on how climate-related events affect the survival and behavior of the infaunal Manila clam V. philippinarum in holding facilities. The results showed that a single stressor of temperature or salinity affected behavior and that these effects can be reflected in mortality rates. Furthermore, the combination of warming and low salinity could lead to mass mortality of V. philippinarum within eight days. Additionally, the combination of heavy precipitation events and increased temperature may affect the survival and behavior of V. philippinarum, and further studies should be conducted on the physiological response of the clams to understand the combined effect of temperature and salinity fluctuations. Based on these results, we recommend that the holding in the summer period should be limited to $1-2$ weeks, with the optimal temperature of $18-21^{\circ} \mathrm{C}$ and the 
optimal salinity range of $>24$ psu. Moreover, this research can help guide the planning of clam fisheries management and can be used in the design and operation.

Author Contributions: Conceptualization, H.B., J.I., S.J., B.C. and T.K.; Methodology, H.B., J.I., S.J. and B.C.; Formal analysis, H.B., J.I., S.J. and B.C.; Investigation, H.B. and J.I.; Writing-original draft preparation, H.B.; Writing-Review \& Editing, T.K.; Supervision, T.K.; Funding acquisition, T.K. All authors have read and agreed to the published version of the manuscript.

Funding: This research was a part of the projects "Development of 3-D Ocean Current Observation Technology for Efficient Response to Maritime Distress" and "Gyeonggi Sea Grant Research Program" funded by the Ministry of Oceans and Fisheries (grant number 20210642 and 20170362) and was also supported by National Research Foundation (NRF-2020R1A2C1005194) of Korea.

Institutional Review Board Statement: Not applicable.

Informed Consent Statement: Not applicable.

Data Availability Statement: The data that support the findings of this study are available from the corresponding author upon reasonable request.

Acknowledgments: We would like to thank the Gunpyeong-ri Fishermen's Association for collecting the Manila clams used in the present study. We thank Jiyeong Choi and Minju Kim for their help with the experimental work. We also thank Seojeong Park, and the lab members provided valuable comments throughout the experiment.

Conflicts of Interest: The authors declared no conflict of interests.

\section{References}

1. Hoegh-Guldberg, O.; Jacob, D.; Taylor, M.; Bindi, M.; Brown, S.; Camilloni, I.; Diedhiou, A.; Djalante, R.; Ebi, K.; Engelbrecht, F; et al. Chapter 3: Impacts of $1.5^{\circ} \mathrm{C}$ Global Warming on Natural and Human Systems. In Global Warming of $1.5^{\circ} \mathrm{C}$ : An IPCC Special Report on the Impacts of Global Warming of $1.5^{\circ} \mathrm{C}$ above Preindustrial Levels and Related Global Greenhouse Gas Emission Pathways [...]; IPCC: Geneva, Switzerland, 2018; pp. 175-311.

2. Pachauri, R.K.; Allen, M.R.; Barros, V.R.; Broome, J.; Cramer, W.; Christ, R.; Church, J.A.; Clarke, L.; Dahe, Q.; Dasgupta, P.; et al. Climate Change 2014: Synthesis Report. Contribution of Working Groups i, ii and iii to the Fifth Assessment Report of the Intergovernmental Panel on Climate Change; Pachauri, R.K., Meyer, L., Eds.; IPCC: Geneva, Switzerland, 2014; p. 151.

3. Labat, D.; Goddéris, Y.; Probst, J.L.; Guyot, J.L. Evidence for Global Runoff Increase Related to Climate Warming. Adv. Water Resour. 2004, 27, 631-642. [CrossRef]

4. Skliris, N.; Marsh, R.; Josey, S.A.; Good, S.A.; Liu, C.; Allan, R.P. Salinity Changes in the World Ocean since 1950 in Relation to Changing Surface Freshwater Fluxes. Clim. Dyn. 2014, 43, 709-736. [CrossRef]

5. Bell, J.D.; Ganachaud, A.; Gehrke, P.C.; Griffiths, S.P.; Hobday, A.J.; Hoegh-Guldberg, O.; Johnson, J.E.; Le Borgne, R.; Lehodey, P.; Lough, J.M.; et al. Mixed Responses of Tropical Pacific Fisheries and Aquaculture to Climate Change. Nat. Clim. Change 2013, 3, 591-599. [CrossRef]

6. Brown, C.J.; Fulton, E.A.; Hobday, A.J.; Matear, R.J.; Possingham, H.P.; Bulman, C.; Christensen, V.; Forrest, R.E.; Gehrke, P.C.; Gribble, N.A.; et al. Effects of Climate-Driven Primary Production Change on Marine Food Webs: Implications for Fisheries and Conservation. Glob. Change Biol. 2010, 16, 1194-1212. [CrossRef]

7. Basset, A.; Barbone, E.; Elliott, M.; Li, B.-L.; Jorgensen, S.E.; Lucena-Moya, P.; Pardo, I.; Mouillot, D. A Unifying Approach to Understanding Transitional Waters: Fundamental Properties Emerging from Ecotone Ecosystems. Estuar. Coast. Shelf Sci. 2013, 132, 5-16. [CrossRef]

8. Najjar, R.G.; Pyke, C.R.; Adams, M.B.; Breitburg, D.; Hershner, C.; Kemp, M.; Howarth, R.; Mulholland, M.R.; Paolisso, M.; Secor, D.; et al. Potential Climate-Change Impacts on the Chesapeake Bay. Estuar. Coast. Shelf Sci. 2010, 86, 1-20. [CrossRef]

9. Gosling, E. Marine Bivalve Molluscs, 2nd ed.; Wiley-Blackwell: Hoboken, NJ, USA, 2015.

10. Han, K.; Lee, S.; Wang, S. The Effect of Temperature on the Energy Budget of the Manila Clam, Ruditapes Philippinarum. Aquac. Int. 2008, 16, 143-152. [CrossRef]

11. Kim, T.; Micheli, F. Decreased Solar Radiation and Increased Temperature Combine to Facilitate Fouling by Marine NonIndigenous Species. Biofouling 2013, 29, 501-512. [CrossRef] [PubMed]

12. Anestis, A.; Lazou, A.; Pörtner, H.O.; Michaelidis, B. Behavioral, Metabolic, and Molecular Stress Responses of Marine Bivalve Mytilus Galloprovincialis during Long-Term Acclimation at Increasing Ambient Temperature. Am. J. Physiol. Regul. Integr. Comp. Physiol. 2007, 293, 911-921. [CrossRef]

13. Kim, T.; Lee, J.; Yoo, C. Change of Foraging and Hiding Behaviors in the Pacific Abalone Haliotis Discus Hannai in Response to Elevated Seawater Temperature. Ocean Sci. J. 2020, 55, 383-390. [CrossRef] 
14. Anestis, A.; Pörtner, H.O.; Karagiannis, D.; Angelidis, P.; Staikou, A.; Michaelidis, B. Response of Mytilus Galloprovincialis (L.) to Increasing Seawater Temperature and to Marteliosis: Metabolic and Physiological Parameters. Comp. Biochem. Physiol. A Mol. Integr. Physiol. 2010, 156, 57-66. [CrossRef]

15. Sin, E.; Min, W.; Kim, Y.; Kim, T. Respiration of the Sea Urchin Mesocentrotus Nudus in Response to Large Temperature Fluctuations. Mar. Environ. Res. 2019, 144, 178-185. [CrossRef] [PubMed]

16. Kim, T.; Park, S.; Sin, E. At the Tipping Point: Differential Influences of Warming and Deoxygenation on the Survival, Emergence, and Respiration of Cosmopolitan Clams. Ecol. Evol. 2018, 8, 4860-4866. [CrossRef]

17. Kim, W.; Huh, H.; Huh, S.; Lee, T. Effects of Salinity on Endogenous Rhythm of the Manila Clam, Ruditapes Philippinarum (Bivalvia: Veneridae). Mar. Biol. 2001, 138, 157-162. [CrossRef]

18. Park, S.; Im, J.; Lee, J.; Kim, T. Ocean Freshening Adversely Affects the Food Detection Ability of the Gammarid Amphipod Haustorioides Koreanus. Mar. Freshw. Res. 2021, 72, 1045-1052.

19. Park, S.; Ahn, I.; Sin, E.; Shim, J.; Kim, T. Ocean Freshening and Acidification Differentially Influence Mortality and Behavior of the Antarctic Amphipod Gondogeneia Antarctica. Mar. Environ. Res. 2020, 154, 104847. [CrossRef]

20. Verdelhos, T.; Marques, J.C.; Anastácio, P. Behavioral and Mortality Responses of the Bivalves Scrobicularia Plana and Cerastoderma Edule to Temperature, as Indicator of Climate Change's Potential Impacts. Ecol. Indic. 2015, 58, 95-103. [CrossRef]

21. Moussa, R.M. The Potential Impacts of Low and High Salinities on Salinity Tolerance and Condition Index of the Adult Pearl Oyster Pinctada Imbricata Radiata (Leach, 1814). J. Basic Appl. Zool. 2018, 79, 12. [CrossRef]

22. Sin, E.; Ahn, I.; Park, S.; Kim, T. Effects of Low PH and Low Salinity Induced by Meltwater Inflow on the Behavior and Physical Condition of the Antarctic Limpet, Nacella Concinna. J. Mar. Sci. Eng. 2020, 8, 822. [CrossRef]

23. Carregosa, V.; Velez, C.; Soares, A.M.V.M.; Figueira, E.; Freitas, R. Physiological and Biochemical Responses of Three Veneridae Clams Exposed to Salinity Changes. Comp. Biochem. Physiol. B Biochem. Mol. Biol. 2014, 177-178, 1-9. [CrossRef] [PubMed]

24. Garrabou, J.; Coma, R.; Bensoussan, N.; Bally, M.; Chevaldonné, P.; Cigliano, M.; Diaz, D.; Harmelin, J.G.; Gambi, M.C.; Kersting, D.K.; et al. Mass Mortality in Northwestern Mediterranean Rocky Benthic Communities: Effects of the 2003 Heat Wave. Glob. Change Biol. 2009, 15, 1090-1103. [CrossRef]

25. La Peyre, M.K.; Eberline, B.S.; Soniat, T.M.; La Peyre, J.F. Differences in Extreme Low Salinity Timing and Duration Differentially Affect Eastern Oyster (Crassostrea Virginica) Size Class Growth and Mortality in Breton Sound, LA. Estuar. Coast. Shelf Sci. 2013, 135, 146-157. [CrossRef]

26. Resgalla, C., Jr.; Brasil, E.d.S.; Salomão, L.C. The Effect of Temperature and Salinity on the Physiological Rates of the Mussel Perna Perna (Linnaeus 1758). Braz. Arch. Biol. Technol. 2007, 50, 543-556. [CrossRef]

27. Yuan, W.S.; Walters, L.J.; Brodsky, S.A.; Schneider, K.R.; Hoffman, E.A. Synergistic Effects of Salinity and Temperature on the Survival of Two Nonnative Bivalve Molluscs, Perna Viridis (Linnaeus 1758) and Mytella Charruana (d'orbigny 1846). J. Mar. Biol. 2016, 2016, 9261309. [CrossRef]

28. Kim, T.; Barry, J.P.; Micheli, F. The Effects of Intermittent Exposure to Low-PH and Low-Oxygen Conditions on Survival and Growth of Juvenile Red Abalone. Biogeosciences 2013, 10, 7255-7262. [CrossRef]

29. Przeslawski, R.; Byrne, M.; Mellin, C. A Review and Meta-Analysis of the Effects of Multiple Abiotic Stressors on Marine Embryos and Larvae. Glob. Change Biol. 2015, 21, 2122-2140. [CrossRef] [PubMed]

30. Barange, M.; Bahri, T.; Beveridge, M.C.M.; Cochrane, K.L.; Funge Smith, S.; Poulain, F. Impacts of Climate Change on Fisheries and Aquaculture: Synthesis of Current Knowledge, Adaptation and Mitigation Options; FAO Fisheries and Aquaculture Technical Paper No. 627; FAO: Rome, Italy, 2018; p. 628.

31. Doney, S.C.; Ruckelshaus, M.; Emmett Duffy, J.; Barry, J.P.; Chan, F.; English, C.A.; Galindo, H.M.; Grebmeier, J.M.; Hollowed, A.B.; Knowlton, N.; et al. Climate Change Impacts on Marine Ecosystems. Annu. Rev. Mar. Sci. 2011, 4, 11-37. [CrossRef]

32. Barrento, S.; Lupatsch, I.; Keay, A.; Christophersen, G. Metabolic Rate of Blue Mussels (Mytilus Edulis) under Varying Post-Harvest Holding Conditions. Aquat. Living Resour. 2013, 26, 241-247. [CrossRef]

33. Gallardi, D.; Hobbs, K.; Mills, T.; Couturier, C.; Parrish, C.C.; Murray, H.M. Effects of Extended Ambient Live Holding on Cultured Blue Mussels (Mytilus Edulis L.) with Reference to Condition Index, Lipid Profile, Glycogen Content and Organoleptic Testing. Aquaculture 2014, 430, 149-158. [CrossRef]

34. Karayücel, S.; Karayücel, İ. The Effect of Environmental Factors, Depth and Position on the Growth and Mortality of Raft-Cultured Blue Mussels (Mytilus Edulis L.). Aquac. Res. 2000, 31, 893-899. [CrossRef]

35. Wyatt, J.; Kenny, S.; Hobbs, K.D.; Mills, T.; Marshall, H.D.; Murray, H.M. The Effect of Extended Wet-Storage on the Condition, Physiology and Stress Response of Cultured Blue Mussels (Mytilus Edulis L. 1758) during Summer and Fall in Northeastern Newfoundland. Aquaculture 2013, 372-375, 111-118. [CrossRef]

36. Wyatt, J.; Kenny, S.; Mills, T.; Marshall, D.H.; Murray, H.M. Condition Index and Neutral Red Assay Response of Cultured Mytilus Edulis 1. Stored in a Wet Holding Facility during Winter and Spring in Northeastern Newfoundland. Fish. Aquac. J. 2014, 5, 1000091.

37. Kang, H.; Lee, Y.; Choi, K.; Park, H.; Yun, S.; Kang, C. Combined Effects of Temperature and Seston Concentration on the Physiological Energetics of the Manila Clam Ruditapes Philippinarum. PLoS ONE 2016, 11, e0152427. [CrossRef]

38. Ponurovsky, S.K.; Yakovlev, Y.U.M. The Reproductive Biology of the Japanese Littleneck, Tapes Philippinarum (A. Adams and Reeve, 1850) (Bivalvia: Veneridae). J. Shellfish Res. 1992, 11, 265-277. 
39. Domínguez, R.; Vázquez, E.; Woodin, S.A.; Wethey, D.S.; Peteiro, L.G.; Macho, G.; Olabarria, C. Sublethal Responses of Four Commercially Important Bivalves to Low Salinity. Ecol. Indic. 2020, 111, 106031. [CrossRef]

40. Joo, S.; Jo, K.; Bae, H.; Seo, H.; Kim, T. Optimal Sediment Grain Size and Sorting for Survival and Growth of Juvenile Manila Clams, Venerupis Philippinarum. Aquaculture 2021, 543, 737010. [CrossRef]

41. Lee, J.; Kim, T. Effects of Potential Future $\mathrm{CO}_{2}$ Levels in Seawater on Emerging Behaviour and Respiration of Manila Clams, Venerupis Philippinarum. ICES J. Mar. Sci. 2017, 74, 1013-1020. [CrossRef]

42. Walne, P.R. Experiments on the Culture in the Sea of the Butterfish Venerupis Decussata L. Aquaculture 1976, 8, 371-381. [CrossRef]

43. Nie, H.; Chen, P.; Huo, Z.; Chen, Y.; Hou, X.; Yang, F.; Yan, X. Effects of Temperature and Salinity on Oxygen Consumption and Ammonia Excretion in Different Colour Strains of the Manila Clam, Ruditapes Philippinarum. Aquac. Res. 2017, 48, 2778-2786. [CrossRef]

44. Huo, Z.; Li, Y.; Golam Rbbani, M.; Wu, Q.; Yan, X. Temperature Challenge on Larvae and Juveniles of the Manila Clam Ruditapes Philippinarum. Aquac. Res. 2018, 49, 1727-1731. [CrossRef]

45. Domínguez, R.; Olabarria, C.; Woodin, S.A.; Wethey, D.S.; Peteiro, L.G.; Macho, G.; Vázquez, E. Contrasting Responsiveness of Four Ecologically and Economically Important Bivalves to Simulated Heat Waves. Mar. Environ. Res. 2021, 164, 105229. [CrossRef]

46. Gómez-Martínez, O.; Aldana-Aranda, D.; Quintana, P.; Pichardo, J.L.; Alvarado-Gil, J.J. Photoacoustic Determination of the Thermal Properties of Bivalve Mollusk Shells. Mar. Biol. 2002, 141, 911-914. [CrossRef]

47. Coughlan, B.M.; Moroney, G.A.; van Pelt, F.N.A.M.; O’Brien, N.M.; Davenport, J.; O'Halloran, J. The Effects of Salinity on the Manila Clam (Ruditapes Philippinarum) Using the Neutral Red Retention Assay with Adapted Physiological Saline Solutions. Mar. Pollut. Bull. 2009, 58, 1680-1684. [CrossRef]

48. Parada, J.M.; Molares, J.; Otero, X. Multispecies Mortality Patterns of Commercial Bivalves in Relation to Estuarine Salinity Fluctuation. Estuaries Coasts 2012, 35, 132-142. [CrossRef]

49. Arisman, N.; Istiqomah, N.; Oka, H.; Yoshimatsu, T. Temporal Change of Salinity Stress in Manila Clam Ruditapes Philippinarum: Implication for Biodefense Mechanism in Response to Climate Change. Aquac. Aquar. Conserv. Legis. 2017, 10, $210-216$.

50. Calabrese, A. Individual and Combined Effects of Salinity and Temperature on Embryos and Larvae of the Coot Clams, Mulinia Lateralis (Say). Biol. Bull. 1969, 137, 417-428. [CrossRef] [PubMed]

51. Whiteley, N.M.; Mackenzie, C.L. Physiological responses of marine invertebrates to thermal stress. In Stressors in the Marine Environment; Oxford University Press: Oxford, UK, 2016.

52. Shin, Y.; Kim, Y.; Chung, E.; Hur, S. Temperature and salinity tolerance of the manila clam, Ruditapes philippinarum. Korean J. Fish Aquat. Sci. 2000, 33, 213-218. 